\title{
From Objectivism to Constructivism: The Effect of a Multimedia Constructivist Learning Environment on Form Four Students' Achievement in Science \& Its Impact on Computer Usage in Learning
}

\author{
Mohd Zahir Shokut Ali \\ ${ }^{1}$ (Centre for Instructional Technology and Multimedia, Universiti Sains Malaysia, Malaysia)
}

\begin{abstract}
This study is conducted to examine the effects of a multimedia constructivist environment on Form Four students' achievement in the learning of "Microorganism and Their Effects on Living Things". The Constructivist Learning Environment (CLE) was developed and is compared with the Ministry of Education courseware, Objectivist Learning Environment (OLE). The purpose of the following study also to examine the impact of CLE vs. OLE use of computer for students. Both on-task (note taking, academic activities) and off-task (email, instant messaging, games, movies) behaviours were examined by surveying students. The CLE was assigned to 34 students whereas the OLE was assigned to 32 students. The independent variables were the multimedia approaches, i.e. the CLE and the OLE, whereas the dependent variable was the students' achievement (postest) and survey results on computer usage. Gender was selected as the moderator variables.

This study found that (i) The students who are using the CLE courseware approach showed a significant difference in their achievement score compared to the students who are using the OLE courseware approach, (ii) The male students did not show a significant difference compared to the female students in their achievement score, (iii) The male students who are using the CLE approach showed a significant difference compared to the male students who are using OLE approach in their achievement score, (iv) The female students who are using the CLE approach showed a significant difference compared to the female students who are using OLE approach in their achievement score and (v) The students who are using the CLE courseware approach showed a significant difference of time spending on computer usage for learning compared to the students who are using the OLE courseware approach Overall, these findings support the positive effect of multimedia constructivist environment on the learning of "Microorganism and Their Effects on Living Things".
\end{abstract}

Keywords :Alessi and Trollip (2001), Constructivist Learning Environment (CLE), Jonassen (1999), Objectivist Learning Environment (OLE),

\section{INTRODUCTION}

With the advent of information technology and a knowledge-based economy, it is imperative to produce knowledgeable workers. Mastery of science and technology among the young is crucial, as this will provide the necessary pool of technocrats who have the capabilities and creativity to take the lead in the various technology related activities. The implications on the school curriculum are obvious. The National Philosophy of Science Education states that, 'In consonance with the National Education Philosophy, science education in Malaysia nurtures a science and technology culture by focusing on the development of individuals who are competitive, dynamic, robust and resilient and able to master scientific knowledge and technological competency'. With this philosophy, science education, therefore, is aimed at developing the potentials of individuals in an overall and integrated manner so as to produce Malaysian citizens who are scientifically and technologically literate, competent in scientific skills, practice good moral values, capable of coping with the changes of scientific and technological advances and be able to manage nature with wisdom and responsibility for the betterment of mankind.Learning is an active process of constructing rather than acquiring knowledge, and instruction is a process of supporting that construction rather than communicating knowledge (Duffy and Cunningham, 1996. p 171). It is argued that the responsibility of learning should reside increasingly with the learner (Von Glasersfeld, 1989). Constructivism thus emphasizes the importance of the learner being actively involved in the learning process, unlike previous educational viewpoints where the responsibility rested with the instructor to teach and where the learner played a passive role. According to Piaget (1967), constructivism is a psychological theory of knowledge (epistemology) which argues that humans construct knowledge and meaning from their experiences. It is a theory describing how learning happens, regardless of whether learners are using their experiences to understand a lecture or following the instructions for building a model airplane. However, constructivism is often associated with pedagogic approaches that promote active learning or learning by doing (Piaget, 1967). 
Social constructivism views each learner as a unique individual with unique needs and backgrounds. The learner is also seen as complex and multidimensional. Social constructivism not only acknowledges the uniqueness and complexity of the learner, but actually encourages, utilizes and rewards it as an integral part of the learning process (Wertsch, 1997).According to the social constructivist approach, instructors have to adapt to the role of facilitators and not teachers (Bauersfeld, 1995). Where a teacher gives a didactic lecture which covers the subject matter, a facilitator helps the learner to get to his or her own understanding of the content. In the former scenario the learner plays a passive role and in the latter scenario the learner plays an active role in the learning process. The emphasis thus turns away from the instructor and the content, and towards the learner (Gamoran, Secada, \&Marrett, 1998). This study intended to design and develop a multimedia constructivist environment to solve the learning difficulties in science. It has been reported that science educators are now realizing that what we teach and what students learn are actually two different things (e.g. Mazur 1992). It turns out that many students are still holding the same misconceptions that they had prior to teaching (e.g. Schneps Sadler 1998).(10)

\section{Background of the Study}

Since the presence of computer in high school classrooms has increased markedly in the past 9 years, today's generation of students has grown up immersed in technology and the Internet. They expect to have constant access to a wide range of technological tools, and laptops are an obvious choice in the classroom (Montgomery, 2009; Palfrey \& Gasser, 2008; Tapscott, 2008). According to Alessi and Trollip(1988) one of the purposes of adding computers to classroom instruction is to facilitate learning for students by improving the quality and quantity of what they know. Schwier andMisanchuk(1993) believe an advantage of interactive multimedia instruction is the creation of meaning developed by the learner's interaction with the new information in the program. So, there is an urge to create a material that is universal and helps students to understand what they are learning and not only remember facts. In Malaysia, the application of computers is now infiltrating all levels and areas of education. Computers, as the technology in the multimedia stream, have long been introduced to Malaysian schools but students use these computers as a tool. Many schools use computers for documentation purposes only but in this age of information technology, the usage of computers as an instructional medium in schools is more imperative due to the huge volume of information that is changing rapidly. Thus, most schools are equipped with computer laboratories but they are hardly used as instructional mediums.

\section{Constructivist Vs. Objectivist}

\section{LITERATURE REVIEW}

Jonassen (1991) points out that the difference between constructivist and objectivist, (behavioral and cognitive), instructional design is that objective design has a predetermined outcome and intervenes in the learning process to map a pre-determined concept of reality into the learner's mind, while constructivism maintains that because learning outcomes are not always predictable, instruction should foster, not control, learning. Within that branch of philosophy known as epistemology, constructivism has been a move away from the earlier ideas about objectivism. Whilst both objectivism and constructivism focus on the experience of the real world, the difference is that "meaning is imposed on the world by us, rather than existing in the world independently of us" (Duffy and Jonassen, 1991 p8). Reeves (1992) indicate the two beliefs can be displayed as a continuum where the objectivists advocate such ideas as:

- Knowledge can be separate from knowing;

- The user gains knowledge objectively through the senses; and

- Learning involves gaining truth that can be measured with tests.

and at the far end of the continuum (after von Glaserfield, 1989) the constructivist theory which focuses on such ideas as

- The existence of knowledge only occurs within humans who construct their own reality;

- Knowledge is constructed subjectively by people based on their earlier experiences and the way people reflect and metacognitively organize these thoughts;

- If the learner acquires the strategies that meet the objective then learning has occurred; and

- Measurement occurs only through estimation with observation or dialogue (Reeves, 1992).

To the objectivists, knowledge and truth exist outside the mind of the individual and are therefore objective. 'Learners are told about the world and are expected to replicate its content and structure in their thinking' (Jonassen, 1991).

\section{Macro Model}

Jonassen (1999) created the model for designing constructivist learning environments (CLEs). According to him, constructivist conceptions of learning assume that knowledge is individually constructed and 
socially co-constructed by learners based on their interpretations of experiences in the world. Since knowledge cannot be transmitted, instruction should consist of experiences that facilitate knowledge construction. The model for designing CLEs conceives of a problem, question, or project as the focus of the environment, with various interpretative and intellectual support systems surrounding it. The goal of the learner is to interpret and solve the problem or complete the project. Related cases and information resources support understanding of the problem and suggest possible solutions; cognitive tools help learners to interpret and manipulate aspects of the problem; conversation/collaboration tools enable communities of learners to negotiate and co-construct meaning for the problem; and social/contextual support systems help users to implement the CLE.

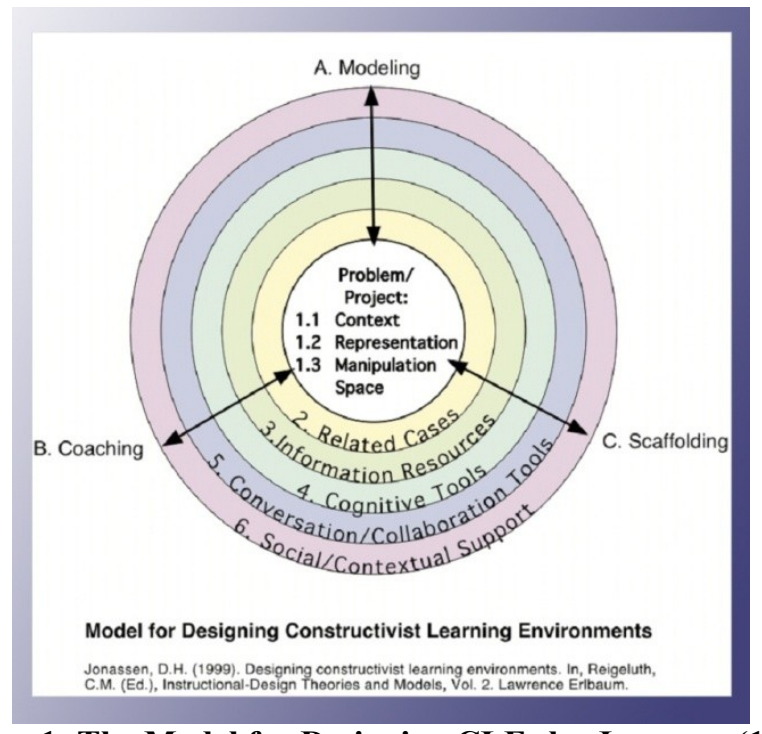

\section{Micro Model}

Figure 1: The Model for Designing CLEs by Jonassen (1999)

Alessi and Trollip (2001) introduced outlines of a model for creating a robust and effective multimedia product. The model is flexible, allowing a person to mold it to his own individual needs and style of work. There are several features that embody this approach. First, it is standards-based. That is, both client and developer should agree on the standards for all aspects of the final product, and throughout the project everyone involved must know what he or she is striving for. As for this study, the standards of the final product were based on the Science syllabus determined by the curriculum department in the Ministry of Education of Malaysia.

Second, it is an empirical approach. Development is based on a cycle of drafting, evaluating and revising until the product works. This model incorporates ongoing evaluation throughout the design and development phase, which prevents costly surprises from surfacing near the end of a project.

The third feature is that a project must be well managed from beginning to end. Multimedia projects have a tendency to get off track and to end up taking more time to produce than planned and costing more than budgeted. With good project management such slippage can be contained while still maintaining desired standards.

The fourth important feature is that this model is driven by principles of cognitive psychology, which are: perception and attention, encoding, memory, comprehension, active learning, motivation, locus of control, mental models, metacognition, transfer of learning, and individual differences. Some constructivist principles are also central: anchored instruction, collaborative learning, and reflective learning.

The fifth feature is the progression from discussion to ideas to implementation. With the profusion of 'integrated' tools, such as Authorware and Tool Book, it is tempting to start developing tools soon. Designers are encouraged to discuss and plan with other people and then drafting ideas before implementing the plans.

The sixth important feature is an emphasis on creativity, especially in the early development process. Creativity is necessary to reveal the capabilities of electronic technology and to encourage people to use the instruction.

The last feature is the encouragement of team-oriented approach. A project team should include people with expertise in instructional design, programming, graphic arts, and the subject matter. When involving more people in the development of a multimedia instruction, more skills and knowledge are involved, thus raising the expected standard of acceptable quality.

Based on these criteria, Alessi and Trollip (2001) created a model for developing interactive multimedia materials that has three attributes: standards, ongoing evaluation and project management; and three phases: planning, design and development. The model is illustrated in Figure 2 


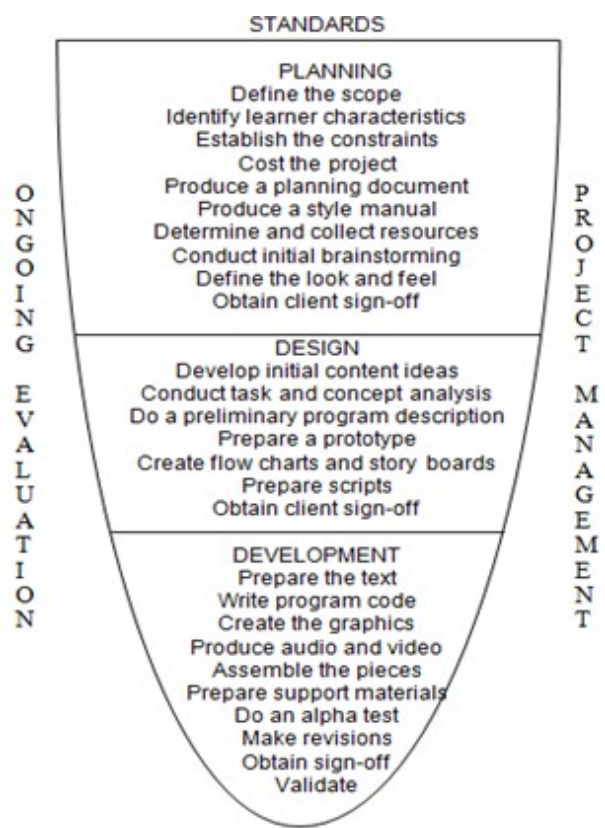

Figure 2: The Model for the Design and Development of the CLE courseware by Alessi and Trollip (2001)

\section{METHODOLOGY}

The purpose of this study is to investigate the effects of constructivist learning environment in learning of 'Microorganisms and Their Effects on Living Things' amongst Form Four students. It also attempted to determine whether any significant difference occurred between the achievement score of the students in the constructivist learning environment (CLE) and the objectivist learning environment (OLE), Ministry of Education courseware approach. It's also to determine the computer usage among students between CLE and OLE courseware.

\section{Design of the Study (Pre Post Test)}

This study is designed based on the quasi-experimental design, with an employment of a 2 × 2 factorial design. The aim of this study is to determine the relationship effect between independent variables and the dependent variables at the two levels of the moderator variable. With total of 5 classes, 2 classes used CLE courseware and another 2 classes used OLE courseware. The remaining class was reserved for PILOT study. Both, the treatment and the control group, were tested with the pretest before conducting the study and posttest after the study, to measure the achievement score. The posttest scores were compared to determine the effectiveness of the treatment. All the 5 classes were given survey questions on the computer usage after Posttest. The research design is illustrated in Figure 3.1 and 3.2

$$
\begin{aligned}
& \mathrm{O}_{1} \rightarrow \mathrm{CLE} \rightarrow \mathrm{O}_{2} \\
& \mathrm{O}_{1} \rightarrow \mathrm{OLE} \rightarrow \mathrm{O}_{2} \\
& \begin{array}{ll}
\mathrm{O}_{1}-\text { Pretest (achievement) } & \text { CLE (Constructivist Leaming Environment) } \\
\mathrm{O}_{2}-\text { Posttest (achievement) } & \text { OLE (Objectivist Leaming Environment) }
\end{array}
\end{aligned}
$$

Figure 3.1: The Achievement Score of Treatment and Control Group Design

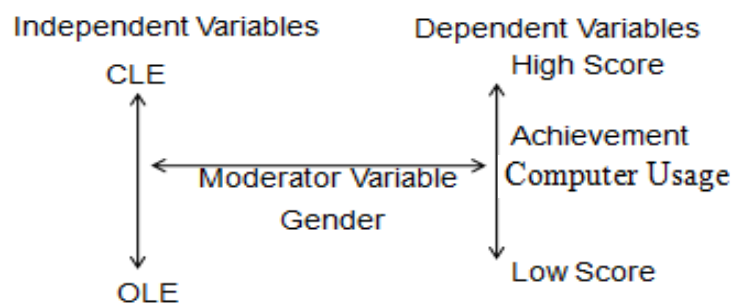

Figure 3.2: The Relationship between Variables 


\section{Variables of the Study (Survey)}

The two independents variables are the OLE courseware, the ready-made courseware which is based on the objectivist theory, and the CLE courseware developed by the researcher based on the constructivist theory. The dependent variables for this survey are:

a) Note taking

b) Academic activities

c) Personal email

d) Instant messaging for personal reasons

e) Games

f) Movies

With total of 5 classes, 2 classes used CLE courseware and another 2 classes used OLE courseware. The remaining class was reserved for PILOT study. Only one school was selected for the study because of time constrain. The students were streamed according to their ability level, by the school administration, based on the PenilaianMenengahRendah (PMR) results. The CLE courseware and the OLE courseware were assigned for both the treatment and control group respectively in the computer laboratory.

\section{Instrument of the Study}

The instruments were the pretest, posttest to measure achievement score and survey were conducted after posttest to measure the amount of time spends by student on computer for learning purposes. (Robin H. Kay and Sharon Lauricella, 2011). The pretest and posttest used in this study was the assessment test which consists of 20 objective questions about the 'Microorganisms and Their Effects on Living Things'. The test was given to the students as pretest before the lesson and as a posttest after going through the lesson. The duration for each test was 20 minutes. The same questions were used as pretest and posttest but were arranged in a randomized order to avoid any possible interaction between them. The test was developed by the researcher and reviewed by a science teacher with 10 years of teaching experience in science. This is to ensure the content and construct validity of the test. Moreover, this step was taken to make sure that the difficulty level of the questions is at an average point. Students were invited to participate in survey. It took approximately 5-10 minutes for students to complete the survey. Each student was asked to rate off-task and on-task behaviors for the course where Constructivist and Objectivist of learning methods use of computer occurred. Each student was asked to rate how much time they spent on in a course that followed either a CLE or OLE format for using computers. Students were required to select one possible response for each behavior:

a) $0=0 \%$ of the time,

b) $1=1-25 \%$ of the time

c) $2=26-50 \%$ of the time

d) $3=51-75 \%$ of the time

e) $\quad 4=76-100 \%$ of the time.

\section{Development of the Courseware}

The OLE courseware used in this study is a readymade item received by all schools from the Curriculum Development Centre of Malaysia. The approach to design the CLE courseware is based on the instructional systems design by Alessi and Trolip (2001) and the Constructivist Learning Environment proposed by Jonassen (1999). The CLE courseware was developed using Macromedia Authorware Version 7.0

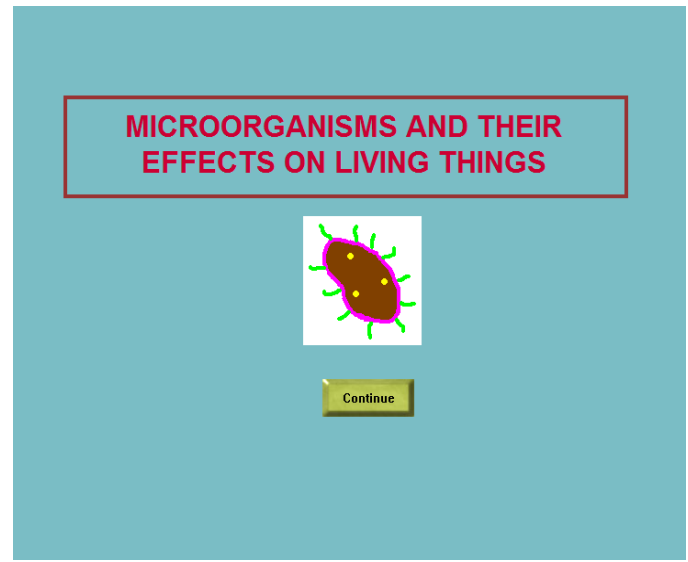

Figure 4 Main Page 


\section{CLE Courseware}

The main menu (Figure 5) displays the main menu with buttons as follows:

(a) Problem solving

(b) Exit

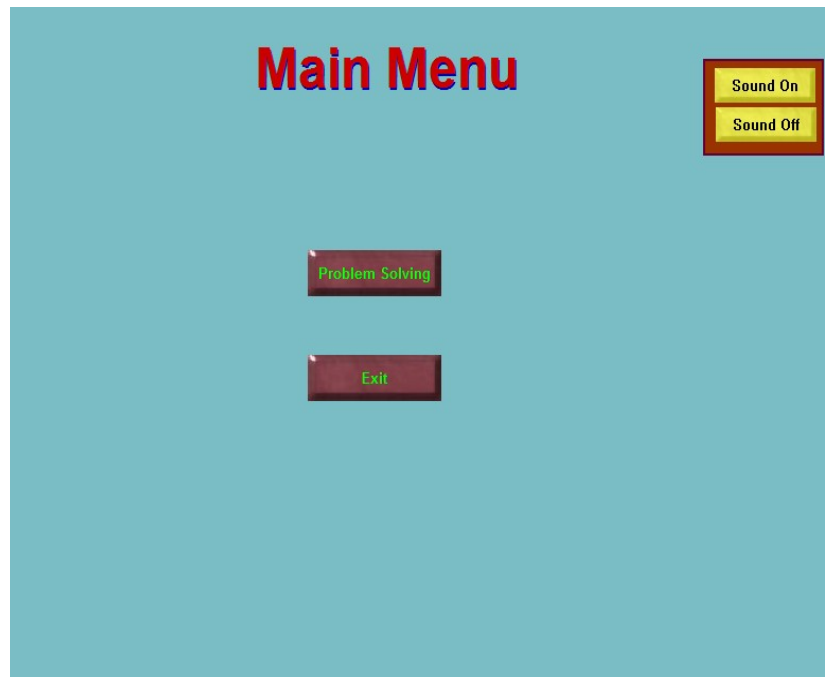

Figure 5 Main Menu Buttons

The "help menu" (Figure 6) has a top menu with five support tools such as:
(a) Related cases
(b) Information Resources
(c) Cognitive tools
(d) Conversation and collaboration tools
(e) Social and contextual support

This top menu is placed in "help" screen to allow the user to access through these tools whenever there is a need.

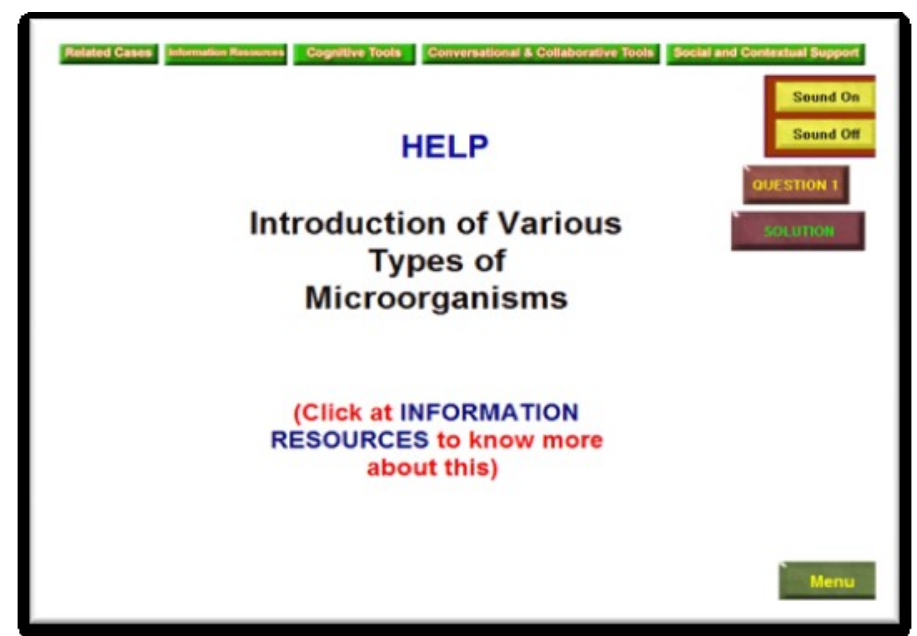

Figure 6 Five Support Tools and Sound Button

There are buttons for "sound on", "sound off" and "menu" on all of the screens. This would enable the user to switch the music on or off or go back to the "main menu" screen whenever he/she decided to do so. The problem solving menu displays the "menu" button, "sound on" button, "sound off" button, "help" button and also navigations to other questions comprised in the problem solving menu. On this screen, the user is expected to try the problems by either clicking on the choice of answers given (Figure 7) or drag and drop the choice of answers into the appropriate boxes (Figure 8), depending on the type of questions displayed. 


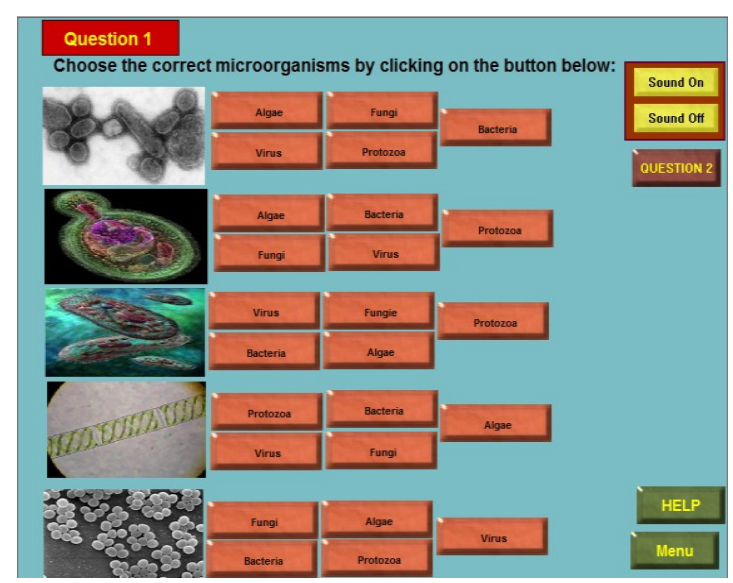

Figure 7 Problem Solving Screen (choosing answers)

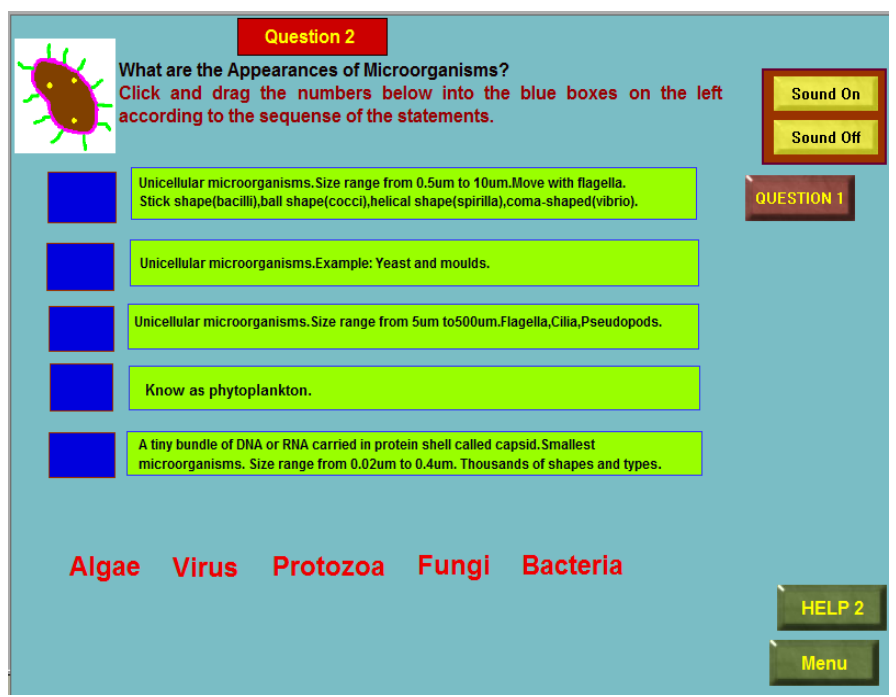

Figure 8 Problem Solving Screen (drag and drop)

There is a pop-up of feedback for the answer the user provided. The positive feedback will be "correct". The negative feedback is "wrong" and the same screen would reappear to give the user another chance to try (Figure 9 and Figure 10). The users could try to solve the problems as many times as they desired. There is a "help" button to assist the user to solve the problems. From this menu, the user would be able to go back to the problem statement screen. If with the "help" button, the user still faced difficulty, he/she could use the solution button to look into the solution of the problem. From the solution screen, the user could also go back to the problem statement screen.

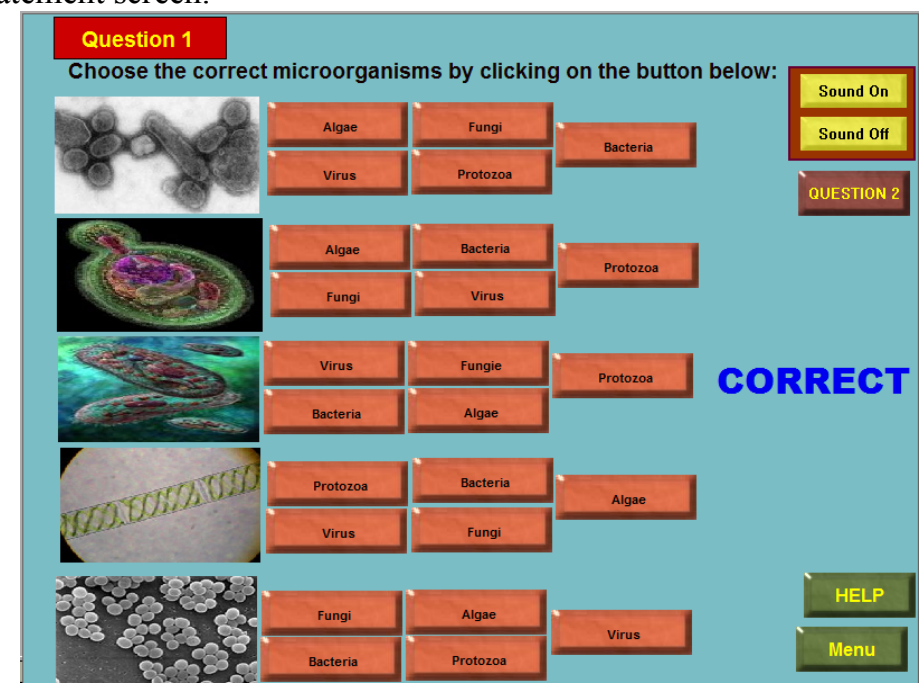

Figure 9 Positive Feedback 


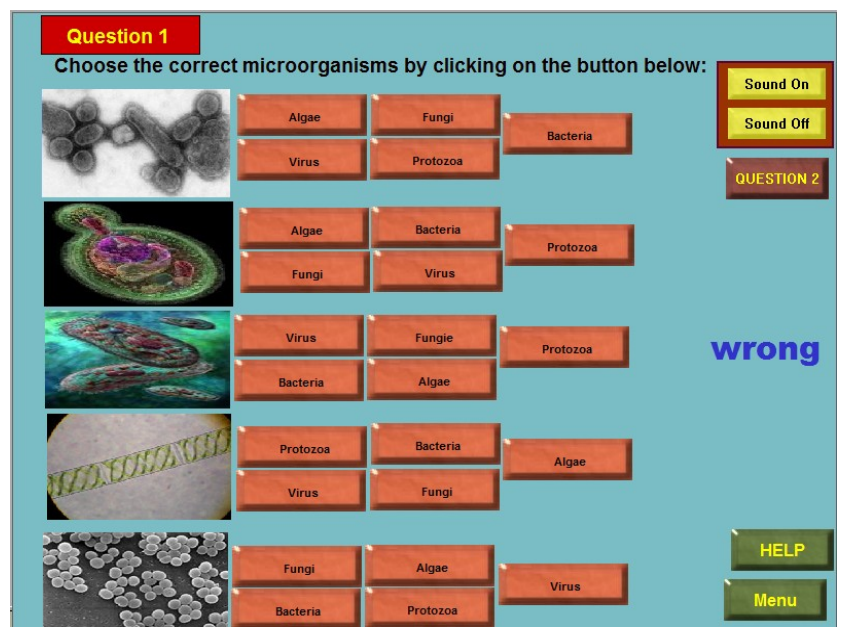

Figure 10 Negative Feedback

If the user still found it difficult to solve the problem, he/she could try the related cases from the top menu. Some guidelines are available on where to go for more help in the "help" screen as shown in Figure 11 and Figure 12, consist of information as follows:
(a) Virus
(b) Bacteria
(c) Algae
(d) Protozoa
(e) Fungi

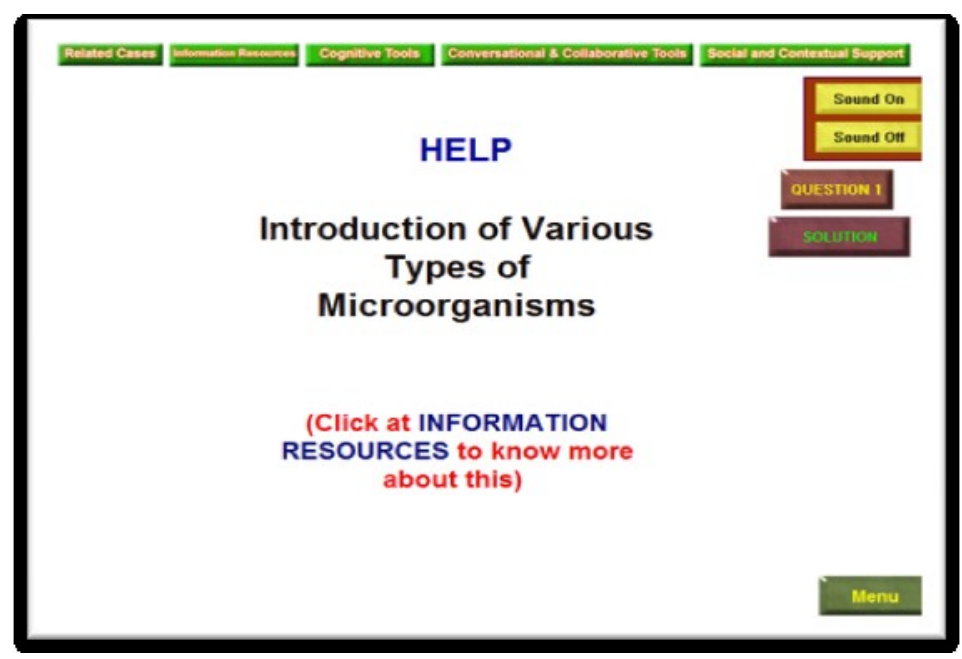

Figure 11 Help

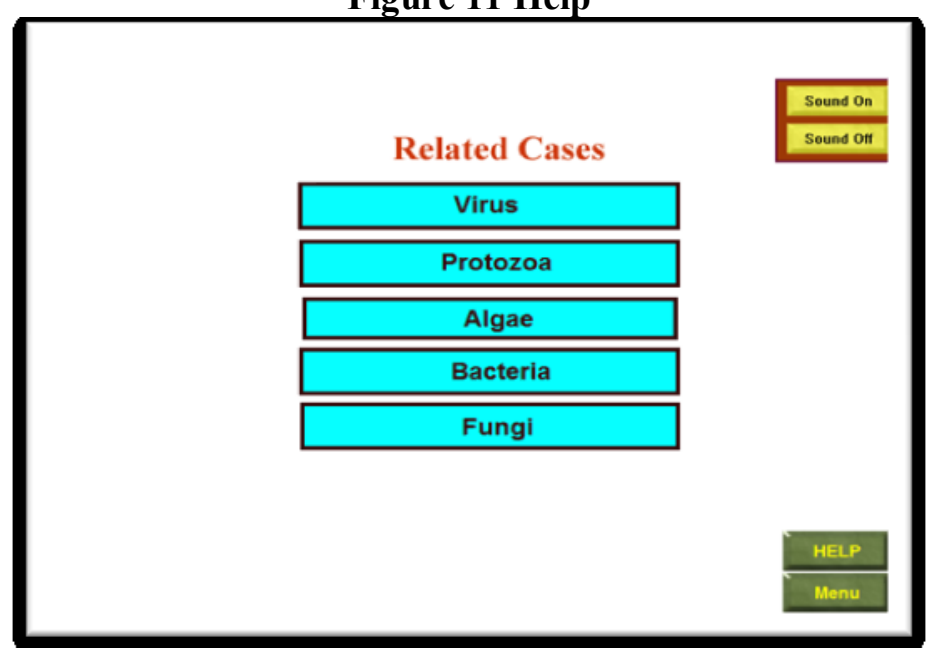

Figure 12 Related Cases 
Each of the above topics displays a few related cases as shown in Figure 13. The user can choose any study case that related to the problem.

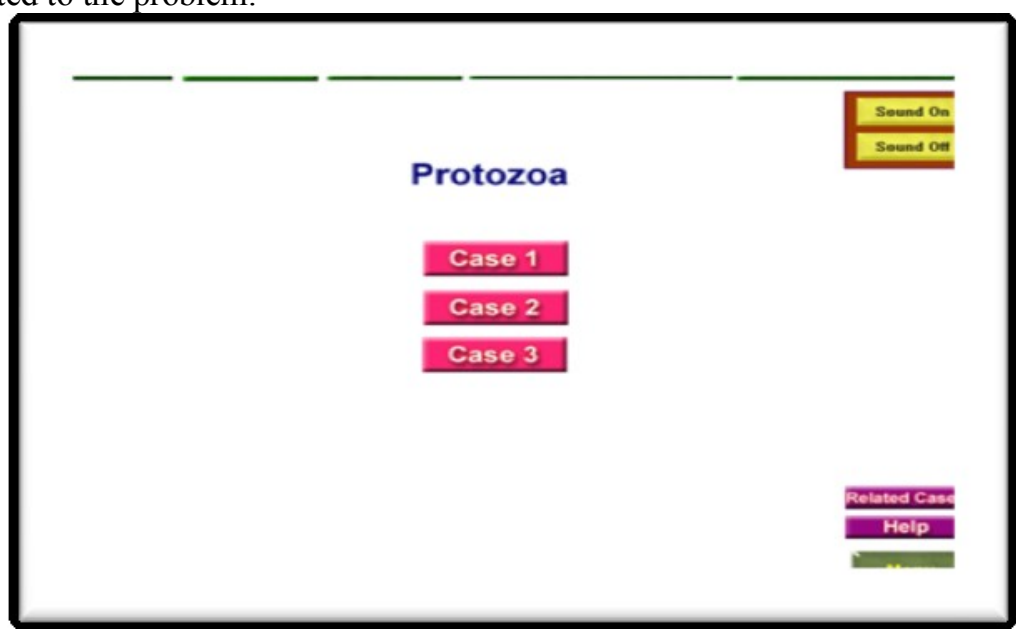

\section{Figure 13 Related Cases for Sub-Topic}

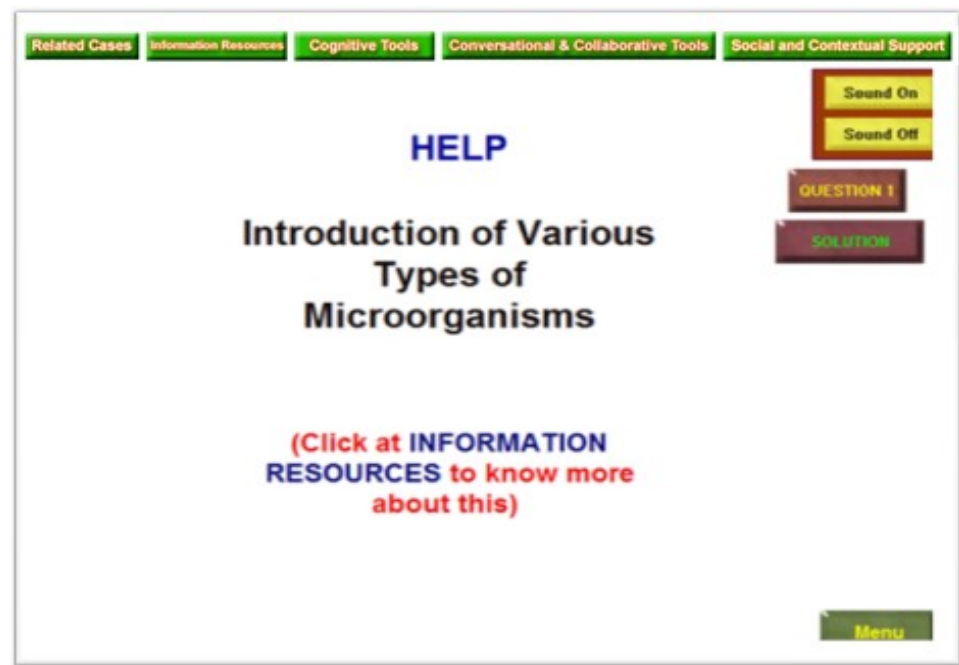

Figure 14 Five Support Tools and Sound Button

The main menu (Figure 14) provided buttons such as the user could use the end button to exit from the program or go back to problem solving page.

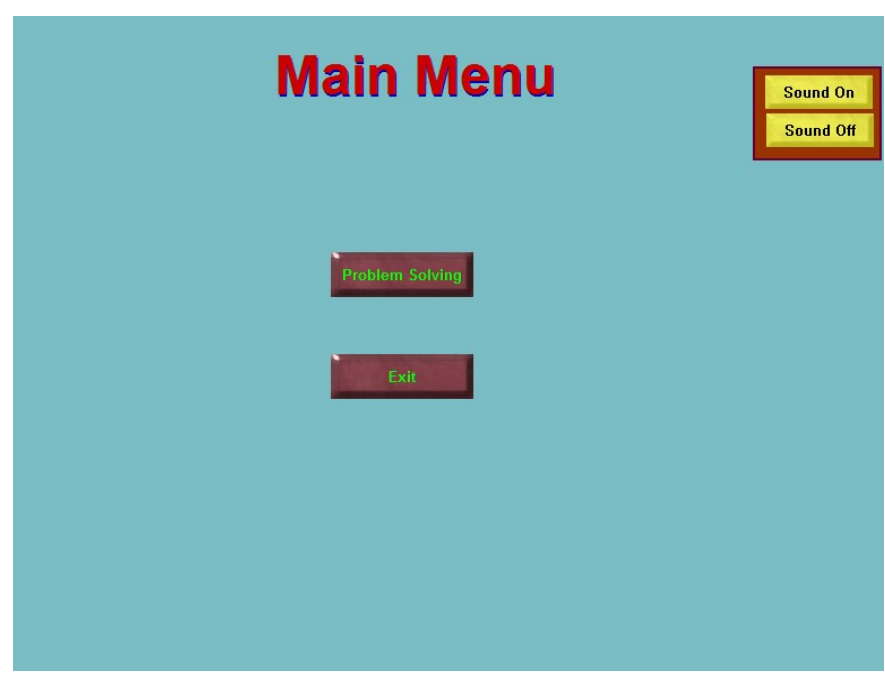

Figure 15 Main Menu Buttons 


\section{FINDINGS}

This chapter presents the results of the study from analyses of the data collected. This study investigated the effects of the Constructivist Learning Environment courseware (CLE) compared to the Objectivist Learning Environment courseware (OLE) in the learning of "Microorganism and Their Effects on Living Things" amongst Form Four students. The independent variables were CLE and OLE courseware. The dependent variable was the achievement scores (the posttest score) and Survey (Computer Usage). The moderator variable was the Gender (Male and Female).

\section{Descriptive Statistics of the Variables}

The variables present in this study were:
(a) Independent Variables
- CLE and OLE courseware
(b) Dependent Variable
- Posttest score, Survey
(c) Moderator Variable
- Gender (male and female)

This study consisted of 66 samples. $32(48.5 \%)$ of them as the control group (OLE) and 34(51.5\%) of them as the treatment group (CLE), as shown in table 1 . The data analyses were carried out using the descriptive and inferential statistics to gather information. The inferential statistics applied in this study were the independent sample t-test, analysis of variance (ANOVA) and Chi-square analysis. The data were compiled and analyzed using the Minitab for Windows computer software version 16.0.

\begin{tabular}{lccc} 
Variable & Frequency & $\begin{array}{c}\text { Percent } \\
(\mathrm{N}=66)\end{array}$ & $\begin{array}{c}\text { (\%) } \\
\text { Moderator }\end{array}$ \\
Variable & Male & 23 & 34.8 \\
Independent & Female & 43 & 65.2 \\
Variable & OLE & 32 & 48.5 \\
\hline CLE & CLE & 34 & 51.5 \\
\hline
\end{tabular}

Notes

CLE: Constructivist Learning Environment courseware

OLE: Objectivist Learning Environment courseware

Table 1 Descriptive Statistics for Independent and Moderator Variables

\section{Inferential Statistics}

Inferential statistics were conducted for the pretest and posttest score. The purpose of the pretest score analysis was to test whether the subjects of the study who learned using CLE and OLE courseware were equivalent in their achievement prior to the treatment session.

\section{Pretest Score Analysis for Independent Variable}

Independent samples t-test was conducted on the pretest score to ascertain the equivalence of the subjects for the two treatment groups in terms of prior knowledge. The pretest score was the dependent variable, whereas the multimedia approach (CLE and OLE courseware) was the independent variable.

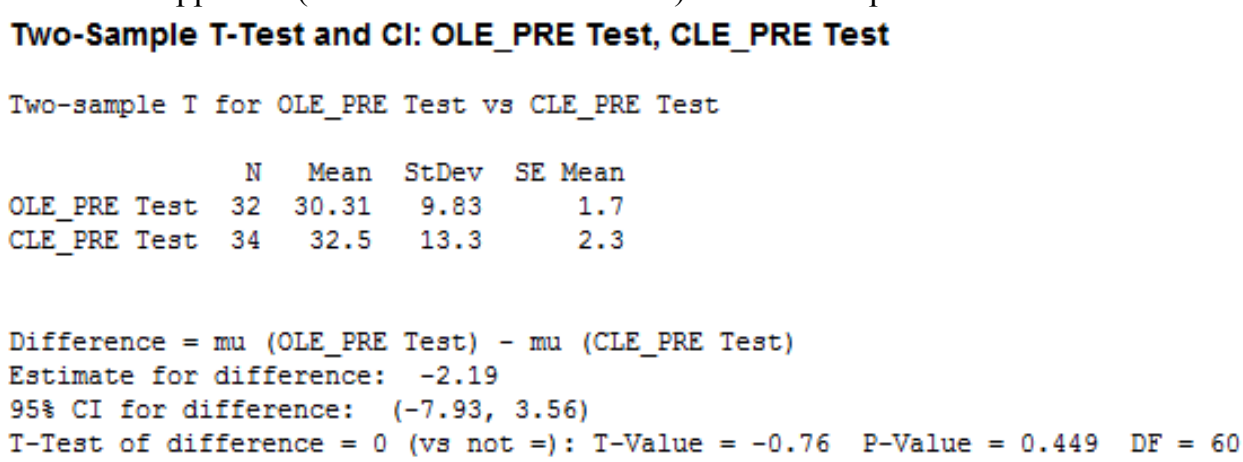

Table 2 Two-sample T test of Pretest Score for Multimedia Courseware

Table 2 shows that there was no significant difference in achievement mean score (pretest score) between the students using the CLE courseware and the students using the OLE courseware $(p=0.449)$. Thus, it can be concluded that the subjects were homogenous in terms of prior knowledge and were distributed randomly between the two treatment groups. 


\section{Achievement Score Analyses for the Independent and Moderator Variable}

$\mathbf{H a}_{1}$ : The students who are using the Constructivist Learning Environment (CLE) courseware approach will show a significant difference in their achievement score compared to the students who are using the Objectivist Learning Environment (OLE) courseware approach.

$\mathrm{Ha}_{2}$ : The male students will show a significant difference compared to the female students in their achievement score.

- $\mathrm{Ha}_{2 \mathrm{a}}$ : The male students will show a significant difference compared to the female students who are using CLE approach in their achievement score

- $\mathrm{Ha}_{2 \mathrm{~b}}$ : The male students who are using the CLE approach will show a significant difference compared to the male students who are using OLE approach in their achievement score

- $\mathrm{Ha}_{2 \mathrm{c}}$ : The female students who are using the CLE approach will show a significant difference compared to the female students who are using OLE approach in their achievement score

\section{Chi-square Analysis for Survey variable on the Multimedia Approach}

The Chi-square test for independence which compares two sets of categories to determine whether the two groups are distributed differently among the categories. (Gibbon, 2006) .39 Students were invited to participate in survey. It took approximately 5-10 minutes for students to complete the survey. Each student was asked to rate off-task and on-task behaviors for the course where Constructivist and Objectivist of learning methods use of computer occurred. Each student was asked to rate how much time they spent on in a course that followed either a CLE or OLE format for using computers. Students were required to select five possible responses for each behavior: a. $76-100 \%$ of the time. b. $51-75 \%$ of the time c. $26-50 \%$ of the time $\mathrm{d} .1-25 \%$ of the time e. $0 \%$ of time

Independent variable -Courseware format (OLE and CLE) was the main independent variable examined in this study. Dependent variables -Based on previous research (Robin H. Kay and Sharon Lauricella, 2011), six dependent variables were used in the current study to compare the impact of CLE vs. OLE use of computer: note taking (on-task) and academic activities (on-task), personal email (off-task), instant messaging for personal reasons (off-task), games (off-task), and movies (off-task). Each student was asked to rate how much time they spent on each specific on- or off-task behavior while participating in a course that followed either a CLE or OLE format for using computer. Students selected five possible responses for each behavior: $0=0 \%$ of the time, $1=$ $1-25 \%$ of the time; $2=26-50 \%$ of the time, $3=51-75 \%$ of the time; and $4=76-100 \%$ of the time.

Ha $_{3}$ : The students who are using the Constructivist Learning Environment (CLE) courseware approach will show a significant difference of time spending on computer usage for learning compared to the students who are using the Objectivist Learning Environment (OLE) courseware approach.

On Task Analysis(Note taking \&Academic Activities)

Off Task Analysis (Personal email, Instant messaging, Games, Movies)

\begin{tabular}{|c|c|c|c|}
\hline $\begin{array}{l}\text { Main Hypothesis/ } \\
\text { Sub-Hypothesis }\end{array}$ & Hypothesis & Results & Details \\
\hline $\begin{array}{l}\mathrm{Ha}_{1} \\
\text { (Overall) }\end{array}$ & $\mathrm{X}_{\mathrm{CLE}}>\mathrm{x}_{\mathrm{OLE}}$ & Accepted & $\begin{array}{l}\text { CLE mean }=8.39 \\
\text { OLE mean }=6.48 \\
(F=14.678, p=0.000)\end{array}$ \\
\hline $\begin{array}{l}\mathrm{Ha}_{2} \\
\text { (Overall) }\end{array}$ & $\mathrm{X}_{\mathrm{M} \text { (al }}>\mathrm{X}_{\mathrm{Female}}$ & Rejected & $\begin{array}{l}\text { M mean }=38.39 \\
F \text { mean }=35.13 \\
(p=0.314)\end{array}$ \\
\hline $\begin{array}{l}\mathrm{Ha}_{2 \mathrm{a}} \\
(\mathrm{CLE})\end{array}$ & $\mathrm{X}_{\mathrm{Male}}>\mathrm{X}_{\text {Female }}$ & Rejected & $\begin{array}{l}\text { M mean }=45.83 \\
F \text { mean }=40.68 \\
(p=0.214)\end{array}$ \\
\hline $\begin{array}{l}\mathrm{Ha}_{2 b} \\
\text { (Male) }\end{array}$ & $\mathrm{X}_{C L E}>\mathrm{X}_{\mathrm{OLE}}$ & Accepted & $\begin{array}{l}M(C L E) \text { mean }=45.88 \\
M(O L E) \text { mean }=26.82 \\
(p=0.000)\end{array}$ \\
\hline $\begin{array}{l}\mathrm{Ha}_{2 c} \\
\text { (Female) }\end{array}$ & $\mathrm{X}_{C I E}>\mathrm{X}_{\mathrm{OLE}}$ & Accepted & $\begin{array}{l}F(C L E) \text { mean }=41.18 \\
F(O L E) \text { mean }=31.90 \\
(p=0.019)\end{array}$ \\
\hline $\begin{array}{l}\mathrm{Ha}_{3} \\
\text { (Survey Computer } \\
\text { Usage) }\end{array}$ & $\mathrm{X}_{C L E}>\mathrm{X}_{O L E}$ & Accepted & $\begin{array}{l}\text { On Task }(p=0.000) \\
\text { Off } \operatorname{Task}(p=0.000)\end{array}$ \\
\hline
\end{tabular}

Table 3Summary on the Achievement Score 
$\mathrm{Ha}_{1}$ : The students who are using the Constructivist Learning Environment (CLE) courseware approach showed a significant difference in their achievement score compared to the students who are using the Objectivist Learning Environment (OLE) courseware approach.

$\mathrm{Ha}_{2}$ : The male students did not show a significant difference compared to the female students in their overall (CLE and OLE) achievement score.

- $\mathrm{Ha}_{2 \mathrm{a}}$ : The male students did not show a significant difference compared to the female students who are using CLE approach in their achievement score

- $\mathrm{Ha}_{2 \mathrm{~b}}$ : The male students who are using the CLE approach showed a significant difference compared to the male students who are using OLE approach in their achievement score

- $\mathrm{Ha}_{2 \mathrm{c}}$ : The female students who are using the CLE approach showed a significant difference compared to the female students who are using OLE approach in their achievement score

$\mathrm{Ha}_{3}$ : The students who are using the Constructivist Learning Environment (CLE) courseware approach showed a significant difference of time spending on computer usage for learning compared to the students who are using the Objectivist Learning Environment (OLE) courseware approach.

\section{DISCUSSION}

The constructivist component that is applied in this study for the topic "Microorganism and Their Effects on Living Things" is an inquiry-based learning, and is found to be effective for this topic .There are few studies suggest that several factors need to be considered for future research. First, there are many other approaches or methods of constructing Constructivist Learning Environment that could be included in designing multimedia instruction such as:

a) Inquiry-based learning,

b) Discovery learning

c) Collaborative learning and

d) Cooperative learning

Further research needs to be carried out to ascertain the effectiveness of these approaches in the Constructive Learning Environment.

The Constructivist Learning Environment courseware designed in this study employed the Jonassen's (1999) Constructivist Learning Environment model that consists of coaching, scaffolding and modeling embedded with support tools such as related cases, information resources, cognitive tools, conversational and collaboration tools, social and contextual support tools. Amongst the various tools above, further research is needed to determine which one is the most effective tool.

The sample of the study was selected only from a suburban school due to time constraints. However, this research could be repeated on urban as well as rural schools to investigate the effectiveness of the CLE courseware. The students from urban and rural areas might differ since the socio-economy background is said to have strong influence over their performance in education (Hativa, 1989; Attewell\& Battle, 1997).

Further research could also be extended to mathematics and other science subjects such as physics, biology, additional science, etc. This is to ensure that the Constructivist Learning Environment benefits students from various fields of sciences. The results from different science disciplines might vary according to the subjects. Thus the sample size of this study will be increased as well. The larger sample size will conclude the effectiveness of CLE courseware approach among students and it also will justified whether computer is a main tool or medium in helping students gaining knowledge.

This study is done in the environment when the learning environment is done in the English medium. However, the researcher found that students are still not competent in the English language. Thus, further research needed to be done to ascertain to what extent language affects proficiency in science learning.

The purpose of this study was also to explore the role of CLE approach might play in helping to make computer a more productive tool in education classrooms. The evidence suggests that even a relatively modest attempt to integrate meaningful computer activities into a class results in more time being spent on activities that support learning. However, the precise impact of specific teaching strategies that lead to positive or negative computer behavior and ultimately improved learning needs to be examined. In other words, simply increasing the frequency of computer use may not result in more productive use. Evaluating the impact of explicit techniques of using computer would particularly be helpful to instructors and researchers.

\section{REFERENCES}

[1] Alessi, S.M., \&Trollip, S.R. (2001).Multimedia for learning: Methods and development ( $3^{\text {rd }}$ ed.). Boston, MA: Allyn\& Bacon.

[2] Aviram A, Eshet-Alkalai Y (2006). Towards a Theory of Digital Literacy: Three Scenarios for the Next Steps. Eur. J. Open, Distance and ELearning, Retrieved May 11, 2007, from http://www.eurodl.org/

[3] Barron, A.E., \&Orwig, G.W. (1995).Multimedia technologies for training. Libraries Unlimited Inc. Englewood, CO

[4] Barak, M., Lipson, A., \&Lerman, S. (2006). Wireless laptops as means for promoting active learning in large lecture halls.Journal of Research on Technology in Education, 38(3), 245-263. 
[5] Bauersfeld, H. (1995). The Structuring of the Structures: Development and Function of Mathematizing as a Social Practice. In L. P. Steffe \& J. Gale (Eds.), Constructivism in Education. Hillsdale, New Jersey: Lawrence Erlbaum Associates Publishers.

[6] Bondarouk TV (2006). Action-oriented group learning in the implementation of information technologies: results from three case studies. Eur. J. Info. Sys., 15: 42-53. Retrieved April 10, 2007, from http://www.palgrave journals.com/ejis/.

[7] Cagiltay NE, Yildirim S, Aksu M (2006). Students' Preferences on Web- Based Instruction: linear or non-linear. J. Edu. Technol. Soc., 9(3): 122-136. Retrieved April 10, 2007, fromhttp://www.ask4research.info

[8] Clark, R.C., \& Mayer, R.E. (2003).e-Learning and the science of instruction. San Francisco, California: Pfeiffer/Wiley Imprint.

[9] Cunningham, D.J. (1991). Assessing constructions and constructing assessments: a dialogue. Educational Technology, 31 (5), 1317.

[10] Dalsgaard C (2006). Social software: E-Learning beyond learning management systems. Eur. J. Open, Distance and E-Learning. Retrieved April 10, 2007, from http://www.eurodl.org

[11] Duffy, T. M., and Cunningham, D. J., (1996). Constructivism: Implications for the design and deliveryof instruction, In D. H. Jonassen, (Ed.) Handbook of Research for Educational Communicationsand Technology, NY: Macmillan Library Reference USA

[12] Ernst von Glasersfeld (1989) Cognition, Construction of Knowledge, and Teaching

[13] Ezziane Z (2007) Information Technology Literacy: Implications on Teaching and Learning. J. Educ. Technol. Soc., 10(3): 175191.Retrieved April 10, 2007, from http://www.ask4research.info/.

[14] Farzana Mohamed Anwar (2009). The Effects of a Multimedia Constructivist Environment On Students' Achievement in the Learning of Coordination Between the Nervous Systemand the Endocrine System Amongst Form Four Students. Unpublished Masters Thesis, UniversitiSains Malaysia

[15] Fong, S.F. (2000). Kesananimasiterhadappembelajaranpengetahuanprosedur meiosis di kalanganpelajarpelbagaiprofilpsikologi. Doctoral Dissertation, Centre for Instructional Technology and Multimedia: UniversitiSains Malaysia.

[16] Fong, S.F., \& Ng, W.K. (2000). Effects of feedback in a multimedia computer-based learning on the achievement of students with different cognitive styles.Proceedings of the SouthEast Asian Regional Symposium on Science and Technology Education, 1, Penang.

[17] Fitch, J. L. (2004). Student feedback in the college classroom: a technology solution. Educational Technology Research and Development,52, 171-181.

[18] Gamoran, A., Secada, W. G., \&Marrett, C. B. (1998). The organizational context of teaching and learning: Changing theoretical perspectives. Handbook of sociology of education.

[19] IsahakHaron, Abdul LatifHj. Gapor, MdNasirMasran, Abdul Halim Ibrahim \& Mariam Mohamed Nor KesanDasarPengajaranMatematikdanSainsdalamBahasaInggeris di SekolahRendah.

[20] Jonassen, D.H. (n.d.) Thinking technology: Toward a constructivist design model.Retrieved May 22, 2004 from http://ourey.cudenver.edu/ slsanfor/cnstdm.txt

[21] Jonassen, D.H. (1991). Objectivism versus constructivism: Do we need a philosophical paradigm? Educational Technology Research and Development, 39 (3), 5-14.

[22] Jonassen, D.H. (1992). Designing hypertext for learning. In. E. Scanlon \& T. O’Shea (Eds.), New directions in education technology (pp.123-131). New York: Springer-Verlag.

[23] Jonassen, D.H. (1996). Computers in the classroom: Mindtools for critical thinking. Columbus, OH: Prentice Hall.

[24] Jonassen, D.H. (1999). Designing constructivist learning environment. In C.M. Reigeluth (Ed.), Instructional design theories and models: A new paradigm of instructional theory. (Vol II, pp. 215-239). Hillsdale, NJ: Lawrence Erlbaum Associates.

[25] Jonassen, D. H., Peck, K. L., \& Wilson, B. G. (1999). Learning with technology: A constructivist perspective. Upper Saddle River, NJ: Merrill/Prentice Hall.

[26] LembagaPeperiksaan, KementerianPelajaran Malaysia (2003). LaporanPrestasiSPM 2002(Jilid II). Kuala Lumpur, Malaysia: Unit Psikometrik, LembagaPeperiksaan,KementerianPendidikan Malaysia.

[27] LembagaPeperiksaan, KementerianPelajaran Malaysia (2004). Laporan Prestasi SPM 2003(Jilid II). Kuala Lumpur, Malaysia: Unit Psikometrik, Lembaga Peperiksaan, Kementerian Pendidikan Malaysia.

[28] Lin, C.H., \& Davidson-Shivers, G.V. (1996).Effects of linking structure and cognitive style on students' performance and attitude in a computer-based hypertext environment. Journal of Educational Computing Research, 15 (4), $317-329$.

[29] Macromedia, Inc. (2001). Authorware6.0 [Computer software]. San Francisco, California: Macromedia Inc.

[30] Montgomery, K. C. (2009). Generation digital. MA: MIT Press.

[31] Piaget, J. (1970). Science of education and the psychology of the child. NY: The Viking Press.

[32] PusatPerkembanganKurikulum, KementerianPelajaran Malaysia (2001). Pembelajaransecarakonstruktivisme. Malaysia

[33] Robin H. Kay and Sharon Lauricella (2011). Unstructured vs. Structured Use of Laptops in Higher Education 2011.

[34] SharifahMaimunahBinti Syed Zin(WORKSHOP ON THE REFORM IN THE TEACHING OF SCIENCE AND TECHNOLOGY AT PRIMARY AND SECONDARY LEVEL IN ASIA:COMPARATIVE REFERENCES TO EUROPE, Beijing, 27-31 March 2000, pg43).

[35] Vickneasvari K, (2007) The Effects Of A Multimedia Constructivist Environment On Students' Achievement and Motivation In The Learning Of Chemical Formulae and Equations, UniversitiSains Malaysia.

\section{APPENDIX 1 \\ MICROORGANISMS AND THEIR EFFECTS ON LIVING THINGS PRE-TEST}

1. What is the diameter range for Bacteria?
A. $0.5-1.0$ micrometers
B. $1.0-1.5$ micrometers
C. 1.5-2.0 micrometers
D. 2.5-3.0 micrometers

2. What is the shape of bacteria?
A. spherical
B. rectangle
C. triangle 
D. square

3. What is the method of reproduction for Protozoa?
A. conjugation
B. budding
C. formation of spores
D. multiply inside living cell.

4. Which of the following is Algae?
A. yeast
B. spirogyra
C. mucor
D. influenza

5. Who discovered the first microorganism?
A. Sir Lee Thomson
B. Anton Van Leewnhoek
C. Marry Shelly
D. Charles Mercuy

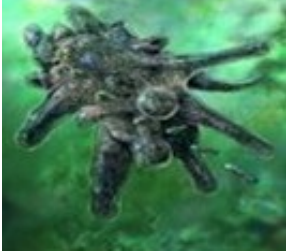

6. Name of microorganism above?
A. Plasmodium
B. Paramecium
C. Amoeba
D. Euglena

7. What is the size of Virus?
A. $20-400 \mathrm{~nm}$.
B. $10-15 \mathrm{~nm}$
C. $400 \mathrm{~nm}-600 \mathrm{~nm}$
D. 2.5-3.0 micrometers

8. Which of the following are Protozoa?
I. Amoeba
II. Plasmodium
III. Paramecium
a) I \& II
b) I \& III
c) II \& III
d) I, II \& III

9. What is Yeast?
A. Bacteria
B. Fungi
C. Virus
D. Algae

10. What is the type of microorganism based on image below? 


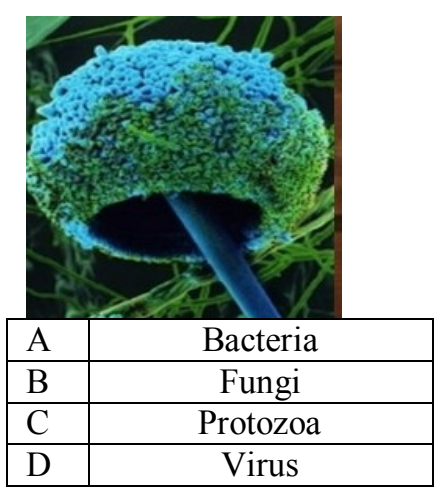

11. Which of the following is not the habitat for Algae?
A. Freshwater
B. Saltwater
C. soil
D. moist area

12. What are the characteristics of Bacteria?
I.
A. I \& II
B. I \& III
C. II \& III
D. I, II \& III

II. Move with help of cilia

III. Do not have nuclear membrane

13. What is the type of microorganism based on image below?

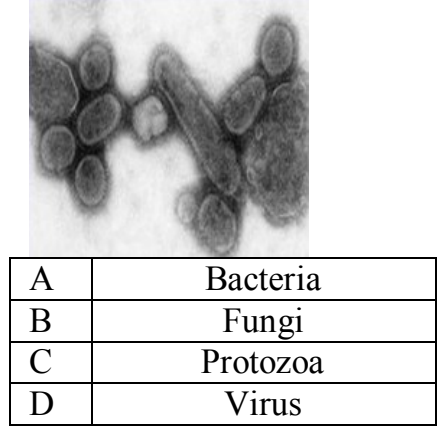

14. What is the type of microorganism based on image below?

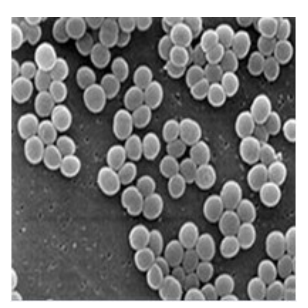

\begin{tabular}{|l|c|}
\hline A & Bacteria \\
\hline B & Fungi \\
\hline C & Protozoa \\
\hline D & Virus \\
\hline
\end{tabular}

15. What are characteristics of Virus?

I. Smallest microorganism

II. Do not carry out any characteristic of living things. 
III. Rectangle shape
A. I and II only
B. I and III only
C. II and III only
D. I, II and III only

16. What is the Nutrition for Virus?
A. Parasitic.
B. Cilia
C. Photosynthesis.
D. Chemosynthesis.

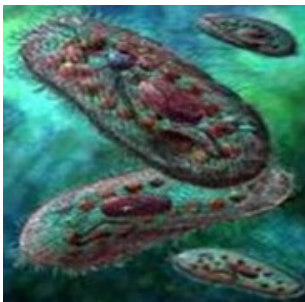

17. What is the type of microorganism based on image above?

\begin{tabular}{|l|c|}
\hline A & Bacteria \\
\hline B & Fungi \\
\hline C & Algae \\
\hline D & Protozoa \\
\hline
\end{tabular}

18. Which is Habitat for Protozoa?
I. Soil
A. I \& II
B. I \& III
C. II \& III
D. I, II \& III

II. Moist area

III. Inside the body of organisms.

19. What are the characteristics of Protozoa?

I. Unicellular organisms

II. Move with help of cilia

III. Move together with the host

IV. Use tentacle to move
A. I \& II
B. III \& IV
C. I, II \& III
D. II, III \& IV

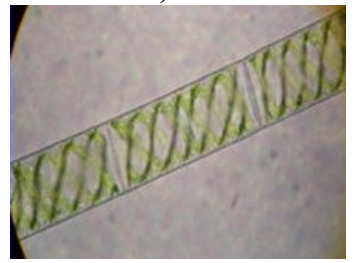

20. What is the type of microorganism based on image above?

\begin{tabular}{|l|c|}
\hline A & Bacteria \\
\hline B & Fungi \\
\hline C & Algae \\
\hline D & Virus \\
\hline
\end{tabular}

APPENDIX 2 


\section{MICROORGANISMS AND THEIR EFFECTS ON LIVING THINGS}

\section{POST-TEST}

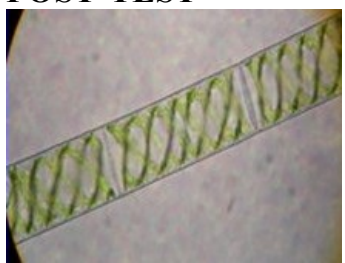

1. What is the type of microorganism based on image above?

\begin{tabular}{|c|c|}
\hline A & Bacteria \\
\hline B & Fungi \\
\hline C & Algae \\
\hline D & Virus \\
\hline
\end{tabular}

2. Which of the following is Algae?
A. yeast
B. spirogyra
C. mucor
D. influenza

3. What is Yeast?
A. Bacteria
B. Fungi
C. Virus
D. Algae

4. What is the shape of bacteria?
A. spherical
B. rectangle
C. triangle
D. square

5. What is the type of microorganism based on image below?

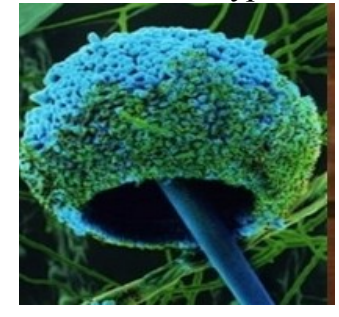

\begin{tabular}{|l|c|}
\hline A & Bacteria \\
\hline B & Fungi \\
\hline C & Protozoa \\
\hline D & Virus \\
\hline
\end{tabular}

6. Who discovered the first microorganism?
A. Sir Lee Thomson
B. Anton Van Leewnhoek
C. Marry Shelly
D. Charles Mercuy

7. What is the size of Virus?
A. $20-400 \mathrm{~nm}$.
B. $10-15 \mathrm{~nm}$
C. $400 \mathrm{~nm}-600 \mathrm{~nm}$
D. 2.5-3.0 micrometers 
8. Which of the following is not the habitat for Algae?
A. Freshwater
B. Saltwater
C. soil
D. moist area

9. What is the method of reproduction for Protozoa?
A. conjugation
B. budding
C. formation of spores
D. multiply inside living cell.

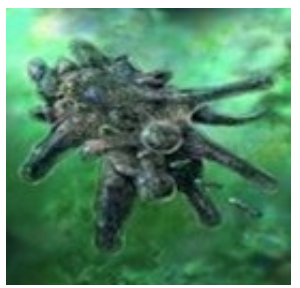

10. Name of microorganism above?
A.Plasmodium
B.Paramecium
C.Amoeba
D. Euglena

11. What is the diameter range for Bacteria?
A.0.5 - 1.0 micrometer
B. 1.0-1.5 micrometers
C.1.5-2.0 micrometers
D.2.5-3.0 micrometers

12. What is the type of microorganism based on image below?

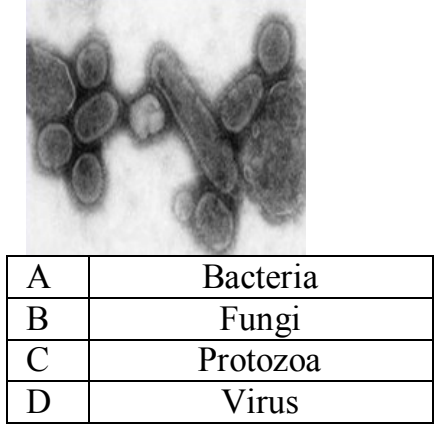

13. What is the type of microorganism based on image below?

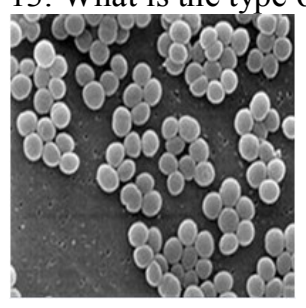

\begin{tabular}{|l|c|}
\hline A & Bacteria \\
\hline B & Fungi \\
\hline C & Protozoa \\
\hline D & Virus \\
\hline
\end{tabular}

14. What are the characteristics of Protozoa?

V. Unicellular organisms 
VI. Move with help of cilia

VII. Move together with the host

VIII. Use tentacle to move
A.I \& II
B. III \& IV
C.I, II \& III
D.II, III \& IV

15. Which of the following are Protozoa?
IV. Amoeba
V. Plasmodium
VI. Paramecium
A. I \& II
B. I \& III
C. II \& III
D. I, II \& III

16. What is the Nutrition for Virus?
A. Parasitic.
B. Cilia
C. Photosynthesis.
D. Chemosynthesis.

17. What are the characteristics of Bacteria?

IV. Unicellular organism

V. Move with help of cilia

VI. Do not have nuclear membrane
A.I \& II
B. I \& III
C. II \& III
D.I, II \& III

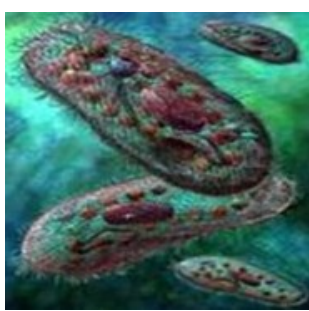

18. What is the type of microorganism based on image above?

\begin{tabular}{|l|c|}
\hline A & Bacteria \\
\hline B & Fungi \\
\hline C & Algae \\
\hline D & Protozoa \\
\hline
\end{tabular}

19. Which is Habitat for Protozoa?
IV. Soil
V. Moist area
VI. Inside the body of organisms.
A.I \& II
B.I \& III
C.II \& III
D.I, II \& III

20. What are characteristics of Virus?

IV. Smallest microorganism

V. Do not carry out any characteristic of living things.

VI. Rectangle shape 

A.I and II only
B.I and III only
C. II and III only
D. I, II and III only

\section{APPENDIX 3}

\section{On- and Off Task Computer Behaviors Survey}

\section{On-Task Behaviors}

1. How much of the lecture time in this course do you use the computer to take notes or follow the lecture?
a. $76-100 \%$ of the lecture time (4)
b. $51-75 \%$ of the lecture time (3)
c. $26-50 \%$ of the lecture time (2)
d. $1-25 \%$ of the lecture time (1)
e. $0 \%$ of the lecture time $(0)$

2. How much of the lecture time in this course do you use the computer for academic purposes relating to this class (i.e., following lecture, doing in-class assignments or activities, viewing course outline, etc.)?
a. $76-100 \%$ of the lecture time (4)
b. $51-75 \%$ of the lecture time (3)
c. $26-50 \%$ of the lecture time (2)
d. $1-25 \%$ of the lecture time (1)
e. $0 \%$ of the lecture time $(0)$

\section{Off-Task Behaviours}

3. How much of the lecture time in this course do you use the computer for email of any kind (Hotmail, Yahoo, gmail, etc.) for purposes other than this course?
a. $76-100 \%$ of the lecture time (4)
b. $51-75 \%$ of the lecture time (3)
c. $26-50 \%$ of the lecture time (2)
d. $1-25 \%$ of the lecture time (1)
e. $0 \%$ of the lecture time $(0)$

4. How much of the lecture time in this course do you use the computer for instant messaging (msn, etc.) for purposes other than the course?
a. $76-100 \%$ of the lecture time (4)
b. $51-75 \%$ of the lecture time (3)
c. $26-50 \%$ of the lecture time (2)
d. $1-25 \%$ of the lecture time (1)
e. $0 \%$ of the lecture time $(0)$

5. How much of the lecture time in this course do you use the computer to play games?
a. $76-100 \%$ of the lecture time (4)
b. $51-75 \%$ of the lecture time (3)
c. $26-50 \%$ of the lecture time (2)
d. $1-25 \%$ of the lecture time (1)
e. $0 \%$ of the lecture time $(0)$

6. How much of the lecture time in this course do you use the computer to watch movies?
a. $76-100 \%$ of the lecture time (4)
b. $51-75 \%$ of the lecture time (3)
c. $26-50 \%$ of the lecture time (2)
d. $1-25 \%$ of the lecture time (1)
e. $0 \%$ of the lecture time (0) 